\title{
Construction of Brazil nut (Bertholletia excelsa: Lecythidaceae) cambium normalized cDNA libraries for 454 next generation sequencing
}

\author{
Peter Inglis, Ana Ciampi, Vânia Azevedo* \\ From IUFRO Tree Biotechnology Conference 2011: From Genomes to Integration and Delivery \\ Arraial d'Ajuda, Bahia, Brazil. 26 June - 2 July 2011
}

\section{Background}

The Brazil nut, Bertholletia excelsa (Lecythidaceae), is the most important non-timber forest resource in the Amazonian biome, where nuts for the international trade are exclusively wild-collected. The monotypic genus possesses a discontinuous distribution and is thought to have rapidly and recently radiated south and westward from a northern/eastern Amazonian origin, largely as a result of ancient human activity [1]. It's genetic variability is currently thought to be low and conserved in one or very few populations [2], and in order to better understand the population genetics of this tree, there is a need for additional, or more informative, molecular markers than is currently available.

\section{Methods}

Trunk cambium is an attractive source of material for cDNA library construction, in contrast to foliar material, where photosynthetic genes are grossly overrepresented. Furthermore, samples can be taken from mature trees at the forest floor level. Cambium samples were collected from both Acre and Amapá states of Brazil, and from both highly, and poorly-productive trees from the respective states, with the aim of detecting microsatellites (SSRs) and single nucleotide polymorphisms (SNPs) for genetic analysis. The samples were frozen in the field on dry ice and later kept at $-80{ }^{\circ} \mathrm{C}$ in the laboratory. Total RNA was extracted from cambium ground with a pestle and mortar under liquid nitrogen, using either the RNeasy kit (QIAGEN) or a combination of hot CTAB pre-treatment with repeated chloroform extraction and the RNeasy kit. Messenger RNA was

\footnotetext{
* Correspondence: vania.azevedo@cenargen.embrapa.br
Laboratório de Genética Vegetal, Embrapa Genetic Resources and

* Correspondence: vania.azevedo@cenargen.embrapa.br
Laboratório de Genética Vegetal, Embrapa Genetic Resources and Biotechnology, Brazilia, Brazil
}

(c) 2011 Inglis et al; licensee BioMed Central Ltd. This is an open access article distributed under the terms of the Creative Commons Attribution License (http://creativecommons.org/licenses/by/2.0), which permits unrestricted use, distribution, and reproduction in any medium, provided the original work is properly cited. purified using oligo dT-magnetic bead separation (Dynabeads; Invitrogen). The Clontech SMART kit and Superscript III (Invitrogen) reverse transcriptase were used for cDNA synthesis and four normalized, PCR-amplified libraries constructed using the Trimmer Direct kit (Evrogen). The four cDNA libraries were multiplex tagged and submitted to a single 454 pyrosequencing production run, using a GS FLX-Titanium instrument.

\section{Results and conclusions}

Cambium RNA extracted with the RNeasy kit alone or with the CTAB pretreatment possessed A260/280 and A260/230 ratios above 2.0, when measured by Nanodrop spectrometry, indicating high purity, and appeared to be of high quality by agarose electrophoresis. However, the RNA extracted by RNeasy alone was not successfully reverse-transcribed and gave no significant products in RT-PCR, even after mRNA purification by magnetic bead separation, indicating the presence of recalcitrant and bound enzyme inhibitory substances. In contrast, the CTAB pretreatment yielded RNA that could be readily reverse transcribed, which was subsequently used for amplified and normalized cDNA library construction.

Data yield for the four normalized libraries averaged 73 million total bases, 270 thousand validated sequences with a mean read length of $265 \mathrm{bp}$, respectively, per library. Sequences were assembled into contigs using Newbler version 2.5 and microsatellites were searched for using Microsatellite Commander v. 0.8.2. The mean numbers of microsatellites identified per repeat class per library were: 507 dinucleotide, 897 trinucleotide, 29 tetranucleotide, 9 pentanucleotide, 41 hexanucleotide, and 138 compound/interrupted repeats, with little variation in microsatellite yield or repeat class present between 
libraries. These libraries appear to be a rich source of new markers, which will greatly enhance our efforts to better understand the population genetics of B. excelsa, to determine appropriate conservation strategies, and to work towards rational selection of productive lines.

Published: 13 September 2011

\section{References}

1. Shepard GH, Ramirez H: "Made in Brazil": Human Dispersal of the Brazil Nut (Bertholletia excelsa, Lecythidaceae) in Ancient Amazonia. Econ Bot 2011, 65:44-65.

2. Buckley DP, O'Malley DM, Apsit V, Prance GT, Bawa KS: Genetics of Brazil nut (Bertholletia excelsa Humb. \& Bonpl.: Lecythidaceae). Theor Appl Genet 1988, 76:923-928.

doi:10.1186/1753-6561-5-S7-P4

Cite this article as: Inglis et al: Construction of Brazil nut (Bertholletia excelsa: Lecythidaceae) cambium normalized CDNA libraries for 454 next generation sequencing. BMC Proceedings 2011 5(Suppl 7):P4.

Submit your next manuscript to BioMed Central and take full advantage of:

- Convenient online submission

- Thorough peer review

- No space constraints or color figure charges

- Immediate publication on acceptance

- Inclusion in PubMed, CAS, Scopus and Google Scholar

- Research which is freely available for redistribution

Submit your manuscript at www.biomedcentral.com/submit
C Biomed Central 